\title{
Tumor-derived exosomes in ovarian cancer - liquid biopsies for early detection and real-time monitoring of cancer progression
}

\author{
Shayna Sharma1 ${ }^{1}$, Felipe Zuñiga2 ${ }^{2}$, Gregory E. Rice ${ }^{1,3}$, Lewis C. Perrin ${ }^{4,5,6}$, John D. \\ Hooper $^{5,6}$ and Carlos Salomon ${ }^{1,2,3,5}$ \\ ${ }^{1}$ Exosome Biology Laboratory, Centre for Clinical Diagnostics, UQ Centre for Clinical Research, Royal Brisbane and Women's \\ Hospital, Faculty of Medicine + Biomedical Sciences, The University of Queensland, Brisbane, Australia \\ ${ }^{2}$ Department of Clinical Biochemistry and Immunology, Faculty of Pharmacy, University of Concepción, Concepción, Chile \\ ${ }^{3}$ Department of Obstetrics and Gynecology, Ochsner Baptist Hospital, New Orleans, Louisiana, USA \\ ${ }^{4}$ Mater Health Services, South Brisbane, Australia \\ ${ }^{5}$ Mater Research Institute, University of Queensland, Translational Research Institute, Woolloongabba, Australia \\ ${ }^{6}$ Mater Ovarian Cancer Research Collaborative, Mater Adult Hospital, South Brisbane, Australia \\ Correspondence to: Carlos Salomon, email: c.salomongallo@uq.edu.au
}

Keywords: ovarian cancer; exosomes; biomarkers; early detection

Received: June 16, $2017 \quad$ Accepted: September 08, $2017 \quad$ Published: October 31, 2017

Copyright: Sharma et al. This is an open-access article distributed under the terms of the Creative Commons Attribution License 3.0 (CC BY 3.0), which permits unrestricted use, distribution, and reproduction in any medium, provided the original author and source are credited.

\section{ABSTRACT}

Ovarian cancer usually has a poor prognosis because it predominantly presents as high stage disease. New approaches are required to develop more effective early detection strategies and real-time treatment response monitoring. Nano-sized extracellular vesicles (EVs, including exosomes) may provide an approach to enrich tumor biomarker detection and address this clinical need. Exosomes are membranous extracellular vesicles of approximately $100 \mathrm{~nm}$ in diameter that have potential to be used as biomarkers and therapeutic delivery tools for ovarian cancer. Exosomal content (proteins and miRNA) is often parent cell specific thus providing an insight or "fingerprint" of the intracellular environment. Furthermore, exosomes can aid cellcell communication and have the ability to modify target cells by transferring their content. Additionally, via the capacity to evade the immune system and remain stable over long periods in circulation, exosomes have potential as natural drug agents. This review examines the potential role of exosomes in diagnosis, drug delivery and realtime monitoring in ovarian cancer.

\section{INTRODUCTION}

Ovarian cancer is the most lethal gynaecological cancer surpassing other malignancies such as uterine and endometrial cancer [1]. The 5-year survival rate for late stage disease is approximately 20\% (Australian Institute of Health and Welfare, 2014) whereas at an early stage, the survival rate is approximately $90 \%$ [2]. Additionally, relapse is almost inevitable in several cases and thus, there is a need for novel therapeutics and tools for both early diagnosis and identification of women at risk of developing ovarian cancer, as well as biomarkers for realtime monitoring of response to therapy [3]. Furthermore, ovarian cancer is a heterogeneous disease with differences between patients presenting at the molecular level $[4,5]$. These differences often mean that whilst one treatment may be effective for a particular patient, it may have no effect in controlling disease for another patient. Therefore, targeted therapies and personalised medicine have become appealing in this field [5]. However, implementing targeted therapies is an arduous task and thus understanding disease progression from the primary tumor leading to metastasis is vital [6]. A primary factor underlying disease progression is cell-cell communication within the tumor microenvironment. This is a poorly understood process although extracellular vesicles, specifically exosomes, 
have received significant attention, being recognized as key mediators $[7,8]$.

Exosomes are small $(\sim 100 \mathrm{~nm})$, membranous vesicles of endocytic origin and can be found circulating in biological fluids such as blood, urine and milk $[9,10]$. Perhaps what makes them most interesting is the idea that exosomes can encapsulate information from the releasing cells, carry signals and relocate packages of information in the tumor microenvironment to ultimately aid metastasis [11, 12]. Moreover, it has been shown that the concentration of plasma exosomal proteins is positively correlated with ovarian cancer disease severity and/or progression [13].

Therefore, this review will summarise the recent advances that have been made in understanding the relationship between ovarian cancer and exosomes. Specifically, the role of exosomes in screening and early detection, as biomarkers for prognosis and drug resistance and as drug delivery vehicles will be discussed.

\section{OVARIAN CANCER}

Despite current advances in research, ovarian cancer retains its position as the leading cause of gynaecological related deaths in females worldwide [1, 14]. Subtypes of ovarian cancer can be histologically differentiated based on tumor biological behaviour and risk factors [15]. The majority of ovarian tumors can be grouped into three major categories depending on the cell of origin, which can be either epithelial, germ or stromal cells although malignant ovarian tumors of epithelial origin are the most common [16]. Carcinomas account for approximately $90 \%$ of the cases of ovarian cancer and these can be further distinguished based on histopathology, molecular genetic analysis and immunohistochemistry in to five recognised subtypes. These subtypes are: serous (SC), clear-cell (CCC), endometrioid (EC), mucinous (MC) and transitional cell (Brenner) carcinoma [17, 18].

The International Federation of Gynaecology and Obstetrics (FIGO) [19] has divided the diagnosis of ovarian cancer in to four clinical stages including: Stage I, where the disease is only present in the ovaries; Stage II, where the disease has spread to the fallopian tube, uterus or below the pelvic brim; Stage III, where the disease affects outside the pelvis and either the abdomen or the lymph nodes or both areas; and Stage IV where the disease metastasises to distant areas such as the liver and/or spleen and outside the abdomen such as the lungs often resulting in pleural effusions. The high rate of ovarian cancer mortality can be attributed to the fact that often symptoms are dismissed resulting in an inability to detect the disease at an early stage. The nature of symptoms is generally vague with commonly reported factors being abdominal pain and/or swelling and changes in bowel habits [20]. Furthermore, methods for estimation of susceptibility are also lacking as there are no known genetic mutations that can be identified in all patients presenting with a particular subtype of ovarian cancer.

\section{Estimation of susceptibility}

Nonetheless, the most well-known factors involved in ovarian cancer susceptibility are mutations in the BRCA1 and BRAC2 genes [21] which are also related to breast cancer susceptibility. The involvement of these genes was identified early on when it was shown that BRCA1 mutations resulted in increased lifetime risk of developing breast-ovarian cancer with multiple cases reported in families [22]. Later research suggested that genetic testing for mutations in BRCA1 and BRCA 2 be considered where there is a family history of either breast or ovarian cancer. However, genetic testing to determine susceptibility is recommended in cases with either Jewish ancestry or a family history of breast and/or ovarian cancer [23]. Another disadvantage to genetic testing is that it is expensive and therefore should be aimed at individuals most at risk. To identify these individuals, several mathematical models have been proposed and the advantages and disadvantages of these models have been discussed in Antoniou et al (2004) who have also proposed an improvised method [24].

Due to the limitations presented by genetic testing, literature has shifted towards different techniques for susceptibility estimation such as, studying smaller molecules, example, RNA and their contribution to disease. In 2016, Permuth and colleagues suggested that RNA editing, which is a post-transcriptional modification where adenosine is converted to inosine by a family of enzymes known as adenosine deaminases acting on RNA (ADAR), may have a role in epithelial ovarian cancers. ADAR expression levels have been found to be significantly greater in peritoneal fluid obtained from patients with epithelial ovarian cancer compared to patients with benign disease [25]. They concluded that examining ADAR genotyping and/or expression level could be a potential biomarker or risk factor [25]. It has also recently been shown that certain genetic variants lead to increased susceptibility to all subtypes of ovarian cancer whereas other variations confer subtype-specific susceptibility [26].

Approximately $20 \%$ of patients with high-grade serous subtype disease carry mutations (both somatic and germ-line) in the BRCA1 and BRCA2 genes [27]. However, patients with germ-line mutations have better overall survival rates. Mutations in other genes and genetic pathways such as KRAS, BRAF, TP53, PIK3CA, AR1D1A and HER2 have also been associated with the other subtypes of ovarian cancer as well as specific germ-line single nucleotide polymorphisms (SNPs) [26]. In addition to genetic factors, environmental factors such as obesity and smoking have been shown to have a correlation with increased risk [28]. An inverse correlation 
between age of menarche and risk of disease was also noted [29]. The identification of genetic mutations provides an estimation of susceptibility, however remains an expensive option.

\section{Metastasis and negative survival rates}

Another factor that is negatively correlated with survival is the fact that ovarian cancer is a heterogeneous disease and therefore the "one size fits all" approach cannot always be applied to treatments. The different subtypes of ovarian cancer have diverse aetiologies and different sensitivity to treatments [26]. Current treatments most commonly include surgical tumor de-bulking and chemotherapy [30]. The chemotherapeutics generally used are carboplatin and paclitaxel, however there is often relapse [30]. The progression between the different stages of ovarian cancer is minimally understood although cell signaling is thought to be involved. Nonetheless, there are three known pathways through which epithelial ovarian cancer can metastasise: transcoelomic, hematogenous and lymphatic spread [31, 32]. Of these, the most common route of metastasis is via transcoelomic dissemination although this process is poorly understood as it differs from the traditional model of cancer metastasis, the hematogenous spread of cancer cells. [33].

Invasion of the tumor cells into the pelvic and abdominal peritoneum is often representative of tumor aggressiveness [34]. This invasion of disease into a body cavity is defined as transcoelomic metastasis. A detailed review of this process is provided by Tan and colleagues [31]. Briefly, the tumor can arise from three potential sites: the ovarian surface, mesothelium lined peritoneal cavity or the fallopian tube [35]. Following progress in carcinoma tumorigenesis, the cells undergo the Epithelial to Mesenchymal transition (EMT) to become more motile. Single tumor cells or tumor cell clusters then disseminate from the primary tumor into the peritoneal cavity and attach to abdominal organs [34]. Upon attachment, the tumor cells return to their epithelial phenotype and proliferate rapidly leading to increased disease burden. Metastasis and aggressive cell division are often indicators of late stage disease with poor prognosis. Therefore, it is essential that the tumor can be detected when it is limited to the ovaries to improve patient outcomes. However, early detection of ovarian cancer remains a challenge as current detection techniques fall short leading to increased mortality rates.

\section{Current detection techniques}

Cancer Antigen-125 (CA-125) and Trans-vaginal imaging are currently routinely used as screening tests for ovarian cancer [36]. CA-125 is a membrane bound glycoprotein with a high molecular weight [37] and a few splice variants which share the same trans-membrane and intracellular regions [37]. It has been linked to the Epithelial Growth Factor Receptor (EGFR) pathway and is often found on the surface of cells that differentiate to form Mullerian-type epithelium (serous, clear cell and endometrioid ovarian carcinomas) [38]. CA-125 can also be released into the circulation and thus detected using antibodies which can be characterised as OV197, M11 or OC125 type antibodies [39]. Trans-vaginal ultrasound is useful for imaging the ovaries and surrounding organs, however, it is often difficult to distinguish tumor formation from functional cysts in pre-menopausal ovaries. CA-125, on the other hand, is not useful in early diagnosis as up to $50 \%$ of Stage I ovarian cancer patients do not express elevated levels [38]. CA-125 levels can also lead to false positive results with raised levels seen in several other gynaecological conditions such as ovulation, menstruation and pregnancy as well as cancers such as fibroids and cancer of the bladder and liver [36]. A randomised controlled trial also reported that simultaneous screening with CA-125 levels and Transvaginal ultrasounds did not reduce mortality when compared to standard care [40]. Since circulating CA-125 concentration has low sensitivity and specificity, other avenues, such as exosomal CA-125 have also been explored.

Zhao et al (2016) reported the development of a microfluidic chip approach to isolate exosomes that expressed certain markers (Epithelial Cell Adhesion Molecule (EpCAM), CA-125 and CD24) [41]. It was also noted that when anti-EpCAM or anti-CA-125 antibodies were used to capture the exosomes, there was a greater number of exosomes captured in patient samples compared to controls [41]. Therefore, although circulating CA-125 may have low sensitivity and specificity, exosomal CA125 may be used to distinguish between healthy and diseased patients. However, the use of CA-125 positive exosomes as potential biomarkers for ovarian cancer in a clinical setting is yet to be validated. Overall, due to the lack of early detection tools, protective salpingooophorectomy, which is the removal of the ovaries in addition to the fallopian tubes, is recommended [42]. However, this is not always feasible as patients often wish to preserve fertility.

It is thus clear that improved screening tests are required for early detection of disease. These screening tests need to fit a specific criteria including: the test can be performed easily, is inexpensive, clinically validated and highly sensitive and specific [36, 43]. Several approaches that fit these criteria have been proposed to combat the shortcomings of the current techniques, including the use of other tumor markers such as CA-15-3 and carcinoembryonic antigen (CEA) which are both elevated in patients with ovarian cancer [44]. However, these markers have poor correlation with the clinical course of disease. 


\section{Circulating molecules in early detection}

Smaller molecules such as circulating miRNA and cell-free DNA (cf-DNA) have also received attention in recent literature although progress is limited. Kamat and colleagues quantified cf-DNA and reported that patients with epithelial ovarian cancer had higher levels compared to healthy individuals [45]. Furthermore, increased cfDNA levels were correlated with reduced survival rates. However, sensitivity of cf-DNA for detecting early stage disease was only $55 \%$. Shao and colleagues found that patients with ovarian cancer had increased levels of cfDNA and that it also increased with advanced stage disease with sensitivity at $88.9 \%$ [46]. Although the use of cf-DNA concentration is an appealing idea, it is unreasonable as cf-DNA concentration is often increased in tumors affecting multiple organs.

This is also a limitation in the use of miRNA expression as an ovarian cancer early detection tool. Previous studies have identified changes in the expression of multiple miRNA between patients with epithelial ovarian cancer and healthy controls such as Let-7 and miR-205. Let-7 levels decreased in patients with ovarian cancer whereas miR-205 levels were higher [47]. However, increased expression of miR-205 is also seen in other types of cancers such as endometrial carcinomas and squamous cell lung carcinoma. Other pitfalls associated with the use of circulating miRNA as a biomarker involve the unavailability of suitable animal models for miRNA research, lack of reproducibility and the costs associated with miRNA profiling [48, 49]. An in-depth discussion of these challenges can be found in Witwer (2015) and Tiberio et al (2015) [49, 50]. In response to these issues, the focus has shifted towards novel techniques for examining miRNA and protein. Exosomes, which encapsulate and hence protect from degradation multiple molecules such as miRNA, have gained increasing popularity in literature. They provide a minimally invasive method to gain an insight into the tumor microenvironment.

\section{EXOSOMES MAY IMPROVE DIAGNOSTIC PREDICTIVE VALUE}

Cell-cell signaling as well as particles released by tumor cells to aid cellular communication remains a major focus. However, cells release a diverse population of factors including signalling molecules, transmitters, apoptotic bodies and microvesicles. These factors combined with the multitude of other abundant proteins (65-97\% of total proteins) in the blood render it difficult to identify molecules of interest from tumor cells as there is a high signal-to-noise ratio [51, 52]. To tackle this issue, focus has shifted towards extracellular vesicles, specifically exosomes, which provide a better representation of the cellular environment compared to other free molecules. They have been highlighted as it has previously been shown that tumor cells (compared to normal cells) release a greater concentration of exosomes $[53,54]$. Further, exosomes have been implicated in aiding pre-metastatic niche formation thus preparing secondary sites for metastasis $[6,7,55,56]$. Therefore, exosomes (highly stable membranous vesicles) may increase diagnostic accuracy by decreasing the signal-to-noise ratio [51]. Furthermore, exosomes are released by all cells that have been examined till date, including both normal and tumor cells [57], and vary in size with a commonly accepted diameter of approximately $30-100 \mathrm{~nm}[58,59]$.

\section{Exosome biogenesis and release}

The biogenesis of exosomes begins with an inward budding of the plasma membrane leading to the formation of an early endosome. The early endosome then matures to a late endosome. Invagination of the late endosomal membrane leads to the formation, within the endosome, of intraluminal vesicles known as multivesicular bodies. The multivesicular body can then either fuse with a lysosome leading to degradation or fuse with the plasma membrane of the cell leading to the release of exosomes [60-62]. Secretion of exosomes through the fusion of the multivesicular body requires Rab GTPases such as Rab27a and Rab27b [63]. However, release can be prevented using ceramide biosynthesis inhibitor, GW4869 [64]. Although exosome biogenesis has been extensively studied, mechanisms of communication with target cells are yet to be fully elucidated but are thought to be via one of three pathways: the cell receptor-exosome ligand interaction, exosome fusion with the target cell leading to release of exosomal cargo, and internalisation of exosomes by target cells through phagocytosis or lipid-raft mediated endocytosis [65-70].

Exosomes express a range of proteins including those related to multivesicular body biogenesis, such as Alix, TSG101 and members of the tetraspanin family [9]. The diverse origins of exosomes suggest roles in facilitating communication under both normal and pathological conditions. However, the pathway through which they undertake this role is yet to be understood. In addition to roles in cell-cell communication, exosomes are also being evaluated as potential biomarkers particularly because the contents of these extracellular vesicles are cell type specific $[2,71]$. It is also thought that exosome content can be used to determine the metabolic state of the cell of origin.

\section{Exosomes in the tumor microenvironment}

Exosomal cargo is composed of a range of molecules including but not limited to proteins (e.g. cytoskeletal proteins, membrane and fusion proteins and heat shock proteins (HSPs)), cell surface receptors and 
miRNAs [58]. Interestingly, the ability of exosomes to transport molecules such as proteins and miRNA also suggests roles in transforming healthy cells to cancerous cells resulting in a premetastatic niche [72]. MicroRNAs (miRNAs) are small non-coding RNAs that influence gene expression by targeting complementary messenger RNA (mRNA) [73]. miRNAs can aid tumor progression as oncogenes upregulated in disease and as tumor suppressors' downregulated in disease.

The implications of exosomes in various biological processes as well as in pathological conditions have been examined although further research is required. For example, it has been reported that tumor-derived exosomes can promote oncogenic activity in recipient tumor cells. Moreover, exosomes can also aid in the development of suitable microenvironments for tumor growth and progression through processes such as angiogenesis. It has been shown that tumor-derived exosome can promote angiogenesis by activating myofibroblasts and endothelial cells [74]. Exosomes can assist microenvironment development by educating bone marrow-derived cells (BMDC) which are vital to tumor development [12]. BMDCs treated with exosomes isolated from highly metastatic melanoma cells resulted in an increased metastatic behaviour displayed by primary tumors through the education of bone marrow progenitors. The role of exosomes in transferring the oncoprotein MET, which is involved in metastasis by affecting mobilisation, was also elucidated [12]. Furthermore, exosomes can communicate with the immune system to counter antitumor responses thereby promoting pro-tumorigenic behaviour [56]. Furthermore, Philip et al (2015) showed that exosomes obtained from highly metastatic cells can transfer metastatic phenotypes through Epithelial to Mesenchymal Transition (EMT) related proteins to poorly metastatic cells [75].

Therefore, there is increasing research involving extracellular vesicles or exosomes, however, a major challenge is to understand the exact mechanisms underlying the role of exosomes in healthy cell transformation. Thus, the current focus is to decipher these mechanisms to facilitate early detection and prevention of ovarian cancer. Additionally, a challenge that remains in the field of extracellular vesicles is an ability to isolate and characterise exosomes as there is no consensus in current literature regarding an exosome isolation protocol $[76,77]$.

Table 1 presents the different techniques involved in exosome isolation. Due to a lack of characterisation methods, there is confusion in the nomenclature with several different types of microvesicles being referred to as exosomes. However, the implications of this challenge and different isolation techniques have been extensively discussed elsewhere [77-83]. Exosomes and their cargo (proteins, miRNA etc.) have been proposed as valuable resources for understanding the metabolic status of cells and can be utilised as prognostic and diagnostic biomarkers in the context of tumors. A summary of the studies involving extracellular vesicle content and ovarian cancer is presented in Table 2.

\section{Exosomes as early detection biomarkers}

The proposal of personalised medicine by Kewal Jain in 1998 has drastically changed the approach towards cancer research and therapeutics [84]. However, the application of personalised medicine to a large population may only be possible if detailed patient information regarding tumor characteristics or the tumor signature is available. One method to achieve such information is to examine tumor-derived exosomes which are released from the endosomal compartments of a tumor cell, capturing vital information from within the cell. Advantages of using exosomes as biomarkers are that it is found within circulation, allowing for minimally invasive isolation, they contain specific molecules that can provide information about the parent cell as well as the probable target cells and that exosomes can protect information carrying molecules from degradation [84]. Garnier and colleagues (2013) proposed the use of exosomes as biomarkers as they noted that the exosomal content varied depending on whether the cell of origin had an epithelial or mesenchymal phenotype [85]. Taylor and Taylor (2008) compared the miRNA profile of ovarian tumor biopsies with the miRNA profile found within circulating EpCAM positive exosomes [13]. Interestingly, it was shown that the expression levels of specific miRNAs were similar between biopsies and exosomes from the same patient with correlations ranging up to 0.90 [13]. Furthermore, it was noted that the exosomal miRNA profile varied depending on disease state (benign or cancerous).

In 2009, Li et al showed that exosomes found in the circulation of approximately 32 (out of 63) patients with ovarian cancer contained claudins whereas only one out of 50 healthy individuals had claudin expressing exosomes present in their circulation [86]. Claudins are trans-membrane proteins which have been found to have increased expression in the context of ovarian cancer. Furthermore, claudin-3 and claudin-7 expression have an inverse correlation with survival in patients with ovarian cancer [86]. However, determining claudin expression requires a tumor biopsy which can often be an invasive procedure. Therefore, $\mathrm{Li}$ and colleagues examined whether exosomes contained claudins and if this could provide a less invasive diagnostic tool. Using claudin-4 positive exosomes as a biomarker, they obtained 51\% sensitivity and $98 \%$ specificity [86]. Proteomic analysis by Liang et al showed that ovarian cancer cell line derived exosomes contained proteins that were cell specific thus providing avenues for new biomarkers [87].

Kobayashi et al (2014) showed that highly invasive ovarian cancer cell line, SKOV-3 derived exosomes had 
Table 1: Summary of studies involving isolation of EVs in ovarian cancer (1999-2017)

\begin{tabular}{llccc}
\hline EVs & Sample & Disease Type & $\begin{array}{c}\text { EV Isolation } \\
\text { Method }\end{array}$ & Biological Process/ Results \\
& Type(s) & & Reference \\
\hline
\end{tabular}

\section{Biological Fluids}

\begin{tabular}{|c|c|c|c|}
\hline $\begin{array}{l}\text { Shed } \\
\text { membrane } \\
\text { vesicles }\end{array}$ & $\begin{array}{c}\text { Ascitic } \\
\text { Fluid } \\
\text { Serum }\end{array}$ & $\begin{array}{l}\text { Papillary adeno- } \\
\text { carcinoma of the ovary }\end{array}$ & Centrifugation \\
\hline $\begin{array}{l}\text { Membrane } \\
\text { bound } \\
\text { vesicles }\end{array}$ & Ascites & $\begin{array}{l}\text { Stage I-IV malignant } \\
\text { ovarian disease }\end{array}$ & Centrifugation \\
\hline Exosomes & Ascites & $\begin{array}{l}\text { Malignant ovarian } \\
\text { cancer }\end{array}$ & $\begin{array}{c}\text { Centrifugation and } \\
\text { Sucrose Gradient }\end{array}$ \\
\hline Exosomes & Serum & $\begin{array}{l}\text { Serous papillary adeno- } \\
\text { carcinoma (Stages } \\
\text { I-IV), benign ovarian } \\
\text { adenoma, NEOD }\end{array}$ & $\begin{array}{l}\text { Modified magnetic } \\
\text { activated cell sorting } \\
\text { (MACS) procedure } \\
\text { using EpCAM }\end{array}$ \\
\hline Exosomes & Serum & $\begin{array}{l}\text { High-grade serous } \\
\text { ovarian cancer }\end{array}$ & Centrifugation \\
\hline Exosomes & Ascites & $\begin{array}{l}\text { Epithelial ovarian } \\
\text { cancer }\end{array}$ & $\begin{array}{l}\text { Centrifugation and } \\
\text { Density Gradient }\end{array}$ \\
\hline
\end{tabular}

Membrane vesicles in the plasma

of patients are similar to membrane vesicles obtained from cell lines established from the same patient.

Vesicles from all malignant ascites stimulated invasion in cultured malignant ovarian epithelium.

Exosomes isolated from ascites have tumor specific antigens which can be recognised by DCs.

miRNA profiling of exosomes can reflect the tissue miRNA profile.

Exosomes from ovarian cancer patient plasma contain Claudin-4.

Exosomes exist in the ascites of $85.4 \%$ of ovarian cancer patients; however, they did not have any significant in vitro effect on tumor growth or apoptosis.

Epithelial ovarian cancer derived exosomes can be up-taken by macrophages and these exosomes can induce differentiation of macrophages to a more tumorassociated macrophage like phenotype.

Surface-plasmon resonance approach for detection of exosomal proteins. Ascitic

$\begin{array}{lll}\text { Exosomes Ascites } \quad \text { Ovarian cancer } & \begin{array}{l}\text { Nano-plasmonic } \\ \text { (nPLEX) assay }\end{array}\end{array}$
samples were used as they contain a large quantity of exosomes.

The exosomes can be isolated by elution from the device.

Three exosomal tumor markers

ExoSearch Chip

Exosomes Plasma Ovarian cancer

Exosomes Plasma Ovarian cancer
(Immunomagnetic beads)

Graphene oxide/ polydopamine $(\mathrm{GO} /$ PDA) nanointerface chip
(CA-125, CD24 and EpCAM)

were used to isolate exosomes from ovarian cancer patient plasma.

The GO/PDA coating increased the immuno-isolation efficacy whilst decreasing non-specific exosome adsorption. 


\begin{tabular}{lcc}
\hline EVs & $\begin{array}{c}\text { Sample } \\
\text { Type(s) }\end{array}$ & Disease Type \\
\hline Cell-Conditioned Media & \\
Exosomes & Ovarian cancer, colon cancer and \\
& breast cancer cell lines \\
Exosomes & Ovarian cancer, embryonic kidney \\
& and neuroglioma cell lines
\end{tabular}

Exosomes Ovarian cancer cell lines and ADSCs

Exosomes

Exosomes

Exosomes

Exosomes

Exosomes

Exosomes

Exosomes

Exosomes

Exosomes

Epithelial ovarian cancer cell lines.

Ovarian cancer and human embryonic kidney cell lines

Ovarian cancer cell lines and HUVECs

Late stage ovarian cancer cell lines

Ovarian cancer cell lines, normal adipocytes and cancer associated adipocytes

Human ADSCs

Ovarian cancer cell lines
EV Isolation Method
Centrifugation and Sucrose Gradient

Centrifugation and

Sucrose Density

Fractionation

Centrifugation

and Discontinuous

Sucrose Gradient

Centrifugation, Density Cushion and Sucrose Gradient

Centrifugation and Sucrose Cushion
Centrifugation

\section{Centrifugation and Commercial Kit}

Centrifugation

Centrifugation

Centrifugation

Commercial Kit

Centrifugation and Commercial Kit
Claudins can be identified in exosomes isolated from CCM.

Ovarian cancer cells internalise exosomes via endocytic routes.

Treatment with ovarian cancer cell line derived exosomes led to ADSCs displaying tumorassociated myofibroblast characteristics.

Proteomic analysis of OVCAR-3 and IGROV1 exosomes.

miRNA profiling of OVCAR-3 and SKOV-3 exosomes.

Proteomic analysis of OVCAR-3, OVCAR-433, OVCAR-5 and SKOV-3 exosomes.

HEK293 cells were able to uptake IGROV1 and OV420 exosomes. Treatment with IGROV1 cells led to increased invasion and migration of HEK293 cells.

Exosomes from cancer cell lines can enhance proliferation, migration and tube formation with CAOV-3 exosomes exerting a greater effect then SKOV-3 exosomes.

Proteomic analysis showing that the pentose pathway is a major mechanism in exosomes mediated cellular communication.

Exosomes can deliver miR-21 from stromal cells to tumor cells leading to chemo-resistance.

Exosomes from human ADSCs can restrict wound-repair, colony formation and proliferation of ovarian cancer cell lines (A2780 and SKOV-3).

Removal of miR-6126 through exosomes results in increased oncogenic behavior of cancer cells.
(Continued) 


\begin{tabular}{|c|c|c|c|c|}
\hline EVs & $\begin{array}{l}\text { Sample } \\
\text { Type(s) }\end{array}$ & $\begin{array}{l}\text { EV Isolation } \\
\text { Method }\end{array}$ & Biological Process/ Results & Reference \\
\hline Exosomes & $\begin{array}{l}\text { Ovarian cancer and ovarian } \\
\text { epithelial cell lines }\end{array}$ & $\begin{array}{l}\text { Centrifugation and } \\
\text { Filtration }\end{array}$ & $\begin{array}{l}\text { Exosomes transfer CD44 to } \\
\text { surrounding mesothelial cells } \\
\text { leading to disease progression. }\end{array}$ & [6] \\
\hline Exosomes & Ovarian cancer cell lines & Centrifugation & $\begin{array}{l}\text { Exosomes are able to transfer } \\
\text { platinum resistance from } \\
\text { resistant cells to their sensitive } \\
\text { counterparts. }\end{array}$ & [117] \\
\hline EVs & $\begin{array}{l}\text { Ovarian cancer and mesothelial cell } \\
\qquad \text { lines }\end{array}$ & $\begin{array}{l}\text { Filtration and } \\
\text { Centrifugation }\end{array}$ & $\begin{array}{c}\text { EVs from aggressive cells } \\
\text { induce metastatic characteristics } \\
\text { in tumors. Cancer cell derived } \\
\text { EVs also induce apoptosis in } \\
\text { mesothelial cells both in vitro and } \\
\text { in vivo. }\end{array}$ & [118] \\
\hline
\end{tabular}

EVs: Extracellular Vesicles, NEOD: No Evidence of Ovarian Disease, DCs: Dendritic Cells, miRNA: microRNA, EpCAM: Epithelial Cell Adhesion Molecule, CCM: Cell-Conditioned Media, ADSCs: Adipose Tissue Derived Mesenchymal Stem Cells, HUVECs: Human Umbilical Vein Endothelial Cells.

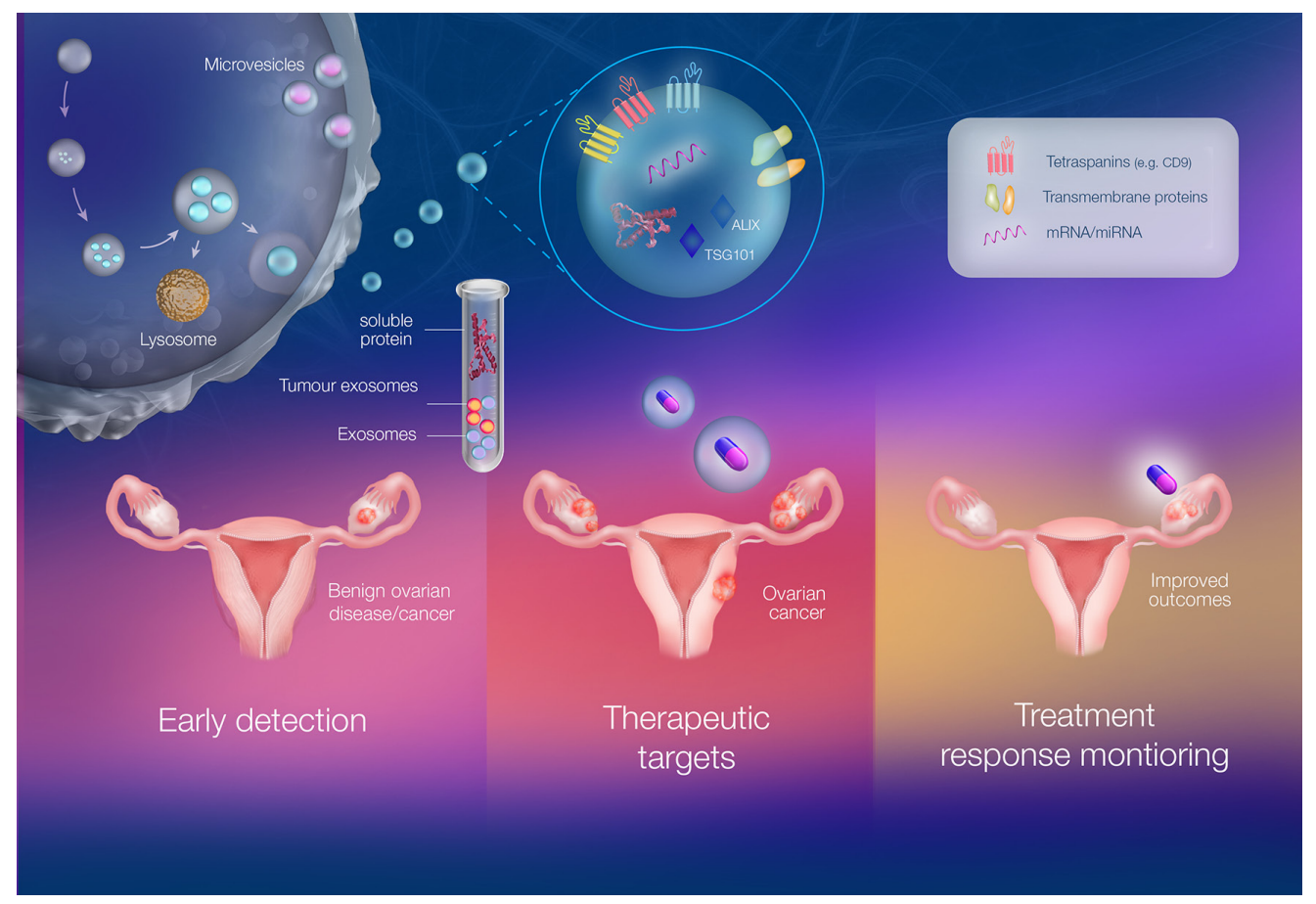

Figure 1: The multi-faceted role of exosomes as liquid biopsies in ovarian cancer involving detection, treatment and monitoring. Exosomes are membranous extracellular vesicles of an endocytic origin. They have been implicated in both physiological and pathophysiological conditions. Exosomes are highly stable and are involved in cell-cell communication and can be considered "fingerprints" of the releasing cell. They also have a capacity to evade the immune system and thus do not elicit an immune response. Exosomes can be found in circulation as well as several bodily fluids such as plasma, urine and saliva allowing for easy identification. The circulating exosomes, once separated from abundant proteins and other vesicles, can be examined under different contexts such as early detection, therapeutics and monitoring cellular response to drugs. This is significant in ovarian cancer as there is currently a lack of early detection methods which is a key contributor to the high mortality rates. Current detection tools include measuring CA-125 levels and Transvaginal ultrasounds. Therefore, exosome concentration, exosomal proteins and miRNA (e.g. exosomal CA-125, EpCAM+ exosomes) have been proposed as early detection tools. Exosomes also provide an avenue for personalised medicine as they are often termed "tumor signatures" and can thus be used as minimally invasive biopsies or natural drug delivery vehicles. Finally, circulating exosome levels and/ or exosomal protein profile after chemotherapy/ treatment can also be used to monitor response to treatment. Thus, exosomes are emerging as liquid biopsies in the context of ovarian cancer to improve survival rates and patient outcomes. 
Table 2: EVs as potential diagnostic biomarkers of ovarian cancer (2009-2017)

\begin{tabular}{|c|c|c|c|c|c|}
\hline EVs & Source(s) & Disease Type & Marker(s) & Results & Reference \\
\hline Exosomes & Serum & $\begin{array}{l}\text { Serous papillary } \\
\text { ovarian } \\
\text { adenocarcinoma, } \\
\text { benign ovarian } \\
\text { adenoma and } \\
\text { no evidence of } \\
\text { disease }\end{array}$ & $\begin{array}{l}\operatorname{miR}-200 c \\
\operatorname{miR}-214\end{array}$ & $\begin{array}{l}\text { Tumor exosomes had similar expression } \\
\text { of certain miRNAs when compared to the } \\
\text { tumor tissue. Expression of miR-200c and } \\
\text { miR-214 was not significantly different } \\
\text { when compared between stages but was } \\
\text { significant when compared to benign } \\
\text { disease. }\end{array}$ & {$[105]$} \\
\hline Exosomes & Plasma & $\begin{array}{l}\text { Ovarian } \\
\text { cancer patients } \\
\text { and healthy } \\
\text { volunteers }\end{array}$ & $\begin{array}{l}\text { Claudins } \\
\text { (Claudin-4) }\end{array}$ & $\begin{array}{l}\text { Claudins can be identified as part of } \\
\text { exosomes shed by ovarian cancer cells } \\
\text { in culture. Further, } 32 \text { out of } 63 \text { ovarian } \\
\text { cancer patient plasma contained Claudin- } 4 \\
\text { positive vesicles compared to } 1 \text { out of } 50 \\
\text { for healthy volunteers. }\end{array}$ & [86] \\
\hline $\begin{array}{l}\text { Micro- } \\
\text { particles }\end{array}$ & $\begin{array}{l}\text { Blood/ } \\
\text { Plasma }\end{array}$ & $\begin{array}{l}\text { Ovarian tumors } \\
\text { with unknown } \\
\text { histology }\end{array}$ & $\begin{array}{l}\text { Concentration of } \\
\text { particles }\end{array}$ & $\begin{array}{l}\text { Concentration of micro-particles was not } \\
\text { enough to distinguish between benign } \\
\text { and malignant cases. However, patients } \\
\text { with ovarian cancer had higher levels of } \\
\text { activated platelet-derived micro-particles } \\
\text { compared to benign disease patients. }\end{array}$ & [119] \\
\hline Exosomes & Ascites & $\begin{array}{l}\text { Ovarian cancer } \\
\text { patients and } \\
\text { portal alcoholic } \\
\text { cirrhosis } \\
\text { patients. }\end{array}$ & Proteins & $\begin{array}{l}40 \% \text { of the proteins found in malignant } \\
\text { ascites could also be found in exosomes. } \\
\text { Exosomes derived from the malignant } \\
\text { ascites had increased exosomal cargo. }\end{array}$ & {$[120]$} \\
\hline Microvesicles & Plasma & $\begin{array}{l}\text { Patients with an } \\
\text { adnexal mass } \\
\text { of unknown } \\
\text { etiology }\end{array}$ & $\begin{array}{l}\text { Microvesicle- } \\
\text { associated } \\
\text { Tissue Factor } \\
\text { Procoagulant } \\
\text { Activity (MV TF } \\
\text { PCA) }\end{array}$ & $\begin{array}{c}\text { Patients with ovarian cancer had an } \\
\text { increase in the concentration of MV TF } \\
\text { PCA }\end{array}$ & [121] \\
\hline Exosomes & Plasma & $\begin{array}{l}\text { Malignant and } \\
\text { benign ovarian } \\
\text { disease }\end{array}$ & $\begin{array}{l}\text { Phosphatidylserine } \\
\text { (PS) }\end{array}$ & $\begin{array}{l}\text { PS-expressing exosomes could be used } \\
\text { to distinguish patients with ovarian } \\
\text { malignancies from patients with no disease. }\end{array}$ & [122] \\
\hline \multicolumn{6}{|l|}{ Cell Lines } \\
\hline Exosomes & \multicolumn{2}{|c|}{ (ovarian cancer cell lines) } & Proteins & $\begin{array}{l}\text { Proteomic analysis of exosomes derived } \\
\text { from the cell lines showed the presence } \\
\text { of cell specific proteins implicating a } \\
\text { role for exosomes as potential diagnostic } \\
\text { biomarkers. }\end{array}$ & [87] \\
\hline Exosomes & \multicolumn{2}{|c|}{$\begin{array}{l}\text { SKOV-3 and OVM (ovarian } \\
\text { cancer cell lines) }\end{array}$} & $\begin{array}{c}\text { LGALS3BP } \\
\text { (sialglycoprotein) }\end{array}$ & $\begin{array}{c}\text { LGALS3BP was identified as an Exosomal } \\
\text { marker from SKOV-3 ovarian carcinoma } \\
\text { cells and N-glycans from the exosomes } \\
\text { were characterised. }\end{array}$ & [123] \\
\hline Exosomes & $\begin{array}{r}\text { OVCAR- } \\
\text { OVCAR } \\
\text { (epithelia } \\
\text { ce }\end{array}$ & $\begin{array}{l}3, \text { OVCAR-433, } \\
-5 \text { and SKOV-3 } \\
1 \text { ovarian cancer } \\
\text { ell lines) }\end{array}$ & Proteins & $\begin{array}{l}\text { Proteomic analysis of exosomes showed } \\
\text { the presence of epithelial ovarian cancer } \\
\text { tissue proteins. }\end{array}$ & [111] \\
\hline
\end{tabular}

(Continued) 


\begin{tabular}{|c|c|c|c|c|c|}
\hline EVs & Source(s) & Disease Type & Marker(s) & Results & Reference \\
\hline $\begin{array}{l}\text { Extracellular } \\
\text { vesicles } \\
(\mathrm{EVs})\end{array}$ & OVMz (or & $\begin{array}{l}\text { arian carcinoma } \\
\text { cells) }\end{array}$ & Glycans & $\begin{array}{l}\text { The presence of galectin-3-binding protein } \\
\text { was noted in the EVs isolated from the } \\
\text { OVMz cells and high expression levels of } \\
\text { galectin-3-binding protein are associated } \\
\text { with shorter survival. }\end{array}$ & [124] \\
\hline Exosomes & $\begin{array}{r}\text { OVCA429 } \\
\text { (ovarian }\end{array}$ & $\begin{array}{l}\text { and HO8910PM } \\
\text { carcinoma cell } \\
\text { lines) }\end{array}$ & $\begin{array}{c}\text { G6PD, } \\
\text { transketolase and } \\
\text { transaldolase } 1\end{array}$ & $\begin{array}{l}\text { Exosomes from both the cell lines } \\
\text { contained G6PD, transketolase and } \\
\text { transaldolase } 1 \text { which are part of the } \\
\text { pentose phosphate pathway and may be } \\
\text { diagnostic of late stage cancer. }\end{array}$ & [114] \\
\hline
\end{tabular}

greater expression of the miRNA, Let-7, when compared to the poorly invasive cell line, OVCAR-3. Additionally, a correlation between the miRNA profiles of OVCAR-3 cell-derived exosomes and the OVCAR-3 parent cells was noted [53]. Vaksman et al (2014) profiled exosomal miRNA expression to analyse the potential of exosomal miRNA as prognostic tools [88]. They found that exosomal miRNAs-21, 23b and 29a correlated with poor survival and it was previously described that miR-21 and miR29a are overexpressed in the serum of ovarian cancer patients [89]. Overall, they stated that cancer cells may be packaging specific miRNA into exosomes which are then released into the effusion fluid. The exosomes can then educate the mesothelial cells leading to the diffusion of the tumor spheres throughout the peritoneal cavity [88].

Therefore, the potential of exosomes as diagnostic and prognostic biomarkers was hypothesised and it was found that several molecules native to the tumor cells/ tissue were expressed in exosomes. This is promising as the expression of low abundance molecules may be masked in circulation but detected in exosomes. In 2004, Graves et al showed that matrix-metalloproteinases MMP-2 and MMP-9 which are related to ovarian cancer metastasis are concentrated in membrane vesicles found within ascites. Furthermore, there are a greater number of these vesicles with increasing disease stage [90]. The utility of exosomes as a minimally invasive biopsy was demonstrated by Runz and colleagues (2007). They determined whether CD24, which is a currently established marker for ovarian cancer prognosis, is present within exosomes. It was revealed that in vitro tumor cell-derived exosomes contained CD24 and that it was also present in exosomes obtained from malignant ascites [91]. Moreover, the miRNA profile of exosomes obtained from patients when compared to tumor tissue profiles from the same patient showed the presence of common miRNA hence highlighting exosomal miRNA as a potential biomarker [47].

\section{Exosomes and drug resistance}

Exosomal research also provides a warrantable avenue in patients that do not respond to standard therapies or patients that present with tumor resistance and/or relapse. Recurrence often occurs between 12-24 months of treatment in advanced disease patients and is accompanied by chemotherapy resistant disease [92]. Research by Au Yeung et al (2016) showed that exosomal miRNA (specifically, miR-21) could induce chemoresistance in ovarian cancer cells. Thus, they suggested that preventing the transfer of miR-21 by exosomes could suppress tumor growth. Literature has also shown that exosomes may have a part in drug resistance as they can increase fibroblast growth which causes a desmoplastic reaction leading to a disruption in treatment delivery [93]. Furthermore, exosomes may also provide a pathway to actively remove drugs leading to a pro-tumorigenic environment.

Safaei et al showed that a cisplatin resistant ovarian cancer cell line released exosomes which had an increased expression of LAMP1 compared to a cisplatin sensitive cell line [94]. LAMP1 is lysosome-associated protein 1 which is a marker associated with lysosomal vesicles (site for cisplatin localisation). Therefore, it was suggested that exosomes were trafficking proteins important for lysosome function thus influencing the development of cisplatin resistance [94]. Yin and colleagues (2012) also proposed a role for exosomes in aiding platinum resistance in ovarian cancer cells [95]. They reported that overexpression of Annexin 3 (A3) provided a pathway for the development of platinum resistance. Fundamentally, they showed that cisplatin resistant ovarian cancer cells released higher amounts of exosomes and that these exosomes contained A3. They also proposed that A3 had a role in the production and fusion of multivesicular bodies leading to the release of exosomes. In contrast to the role of exosomes in drug resistance, exosomes have also been exploited as endogenous nano-carriers for targeted treatments.

\section{Exosomes as drug delivery vehicles}

In addition to their applications in diagnosis and treatment, exosomes provide an invaluable tool for drug delivery and monitoring response. This is attributed to the 
fact that exosomes can encapsulate and transport molecules through compartmentalisation [93]. Specific drug delivery vehicles are appealing as ovarian cancer treatments are often non-specific leading to several side effects. For therapeutic purposes, exosomes can be produced in large quantities using cells with high proliferative capabilities e.g. mesenchymal stem cells (MSC) [96]. These exosomes present a natural drug delivery vehicle as they do not have adverse effects and may be able to target specific tissues [97]. The advantages of using MSC derived exosomes as drug carriers have been discussed in depth by Yeo et al (2013) [96]. Exosomes are also ideal modes of drug delivery as they have a long circulating half-life and biocompatibility [97]. Furthermore, exosomes can surpass the blood brain barrier.

Research by Yang et al (2015) incorporated anticancer drugs, doxorubicin, and paclitaxel, into exosomes and then introduced the exosomes into zebrafish embryos [98]. As a control, they treated the embryos with the drugs alone and found that the drugs were not able to penetrate the blood brain barrier. However, significant amounts of exosomes could penetrate the blood brain barrier leading to cellular uptake of the drugs. Although they were successful in encapsulating drugs into exosomes and delivering them to the target site, they suggested issues that need to be overcome. These issues involve: standardised procedures for isolation and characterisation of exosomes, loading the drugs into exosomes, using peptides to reach the target cells and exosome production from parent cells [98]. Current methods for incorporating substances into exosomes include incubation, electroporation, chemical reagents, and transfection [64]. These methods are discussed in detail in Johnsen et al (2014).

Another study by Tian and colleagues (2014) delivered exosome encapsulated doxorubicin to solid tumors in a mice model [99]. They targeted the exosomes to the tumor cells using an iRGD peptide on the exosomal surface which binds specifically to $\alpha v$ integrins on tumor cells. Incredibly, it was shown that there was a decrease in tumor growth when exosome encapsulated doxorubicin was used compared to an equivalent dosage of free doxorubicin [99]. Exosomes have shown great potential in aiding the premise of personalised medicine as they are equipped with several advantages including an ability to evade the immune system and to carry nano-molecules. It is hoped that the utilisation of exosomes to provide targeted drug delivery remains an active area of research as exosomes represent a non-toxic drug delivery vehicle.

\section{Using exosomes as tools for real-time monitoring of response to therapy}

It has been suggested that circulating exosome levels before and after chemotherapy can be considered to determine a patient's response to the treatment. Szajnik et al (2013) showed that patients that did not respond to treatment with carboplatin and paclitaxel showed no significant change in exosomal protein levels after treatment compared to prior to treatment [100]. Conversely, patients that had a response to the treatments showed either an increase or decrease in exosomal protein levels [100]. Tumor-derived exosomes are also being examined as although exosomes are released under normal physiological conditions, they are found in greater numbers in patients with disease. A possible explanation for this increase is the idea that stressed tumor cells under hypoxia may be releasing signals via exosomes [70]. Since exosomal cargo can have both an immuno-inhibitory and immuno-stimulatory effect, exosomes provide a less invasive method of analysing the immune response to both the tumor and to potential treatments [70].

Whiteside (2015) has suggested that the immunosuppressive molecular profile of tumor exosomes could provide an understanding of the immune dysfunction resulting from the tumor and ultimately tumor progression [70]. This was based on data which showed that the immune-competence of cancer patients can be used to predict outcomes [101, 102]. Overall, exosome concentration and exosomal cargo have been proposed as prognostic biomarkers to monitor the response to treatments. Being aware of treatment response is beneficial as it allows the design of treatment plans suited to the patient rather than general treatment plans. Furthermore, using exosomes in this context may also allow differentiation between patients that will respond to a particular treatment and patients that may not respond.

\section{CONCLUDING REMARKS}

Most significantly, it has been proposed in literature that tumor-derived exosomes may provide a way forward in aiding early diagnosis, drug delivery and monitoring response to treatment in the field of ovarian cancer. Furthermore, exosomal cargo including proteins and miRNA may also provide an insight into the cellular environment including changes in the cell at a molecular level. This ability to gain a snapshot of the internal environment in a timely manner may eradicate the need for invasive biopsies and allow detection of disease prior to metastatic spread. Therefore, exosomes provide a minimally invasive "liquid biopsy" method to gain insight into the tumor microenvironment without the need for a highly invasive tumor biopsy.

However, this achievement is dependent on a complete understanding of exosome biogenesis, secretion, interaction with target cells and the pathways underlying exosomal cell signalling. Additionally, it is important to note that exosomal cargo varies, depending on the releasing cell, and therefore, the process of cargo packaging into exosomes also needs to be fully elucidated. In terms of ovarian cancer, the cross-talk between cells and the microenvironment as well as the involvement 
of exosomes in facilitating this cross-talk also needs to be studied. This review provided a glimpse at the multi-faceted nature of exosomes by discussing recent publications which have aimed to decode the role of exosomes by examining the exosomal cargo, specifically miRNA and proteins. It is anticipated that this review will highlight exosomes as a precious biomedical tool under various contexts as shown in Figure 1 and that research will focus on gaining a deeper understanding of exosomes, exosomal content and their connection with the tumor cells and microenvironment.

\section{CONFLICTS OF INTEREST}

The authors declare no conflicts of interest.

\section{FUNDING}

This review is supported partly by funding from the Lions Medical Research Foundation (LMRF), Ovarian Cancer Research Foundation (OCRF), The University of Queensland and Fondo Nacional de Desarrollo Científico y Tecnológico (FONDECYT 1170809), Chile.

\section{REFERENCES}

1. Ferlay J, Soerjomataram I, Dikshit R, Eser S, Mathers C, Rebelo M, Parkin DM, Forman D, Bray F. Cancer incidence and mortality worldwide: sources, methods and major patterns in GLOBOCAN 2012. Int J Cancer. 2015; 136: E359-86. https://doi.org/10.1002/ijc.29210.

2. Kobayashi M, Rice GE, Tapia J, Mitchell MD, Salomon C. Exosomes are fingerprints of originating cells: potential biomarkers for ovarian cancer. Research and Reports in Biochemistry. 2014: 101-9. https://doi.org/10.2147/RRBC. S58281.

3. Yap TA, Carden CP, Kaye SB. Beyond chemotherapy: targeted therapies in ovarian cancer. Nat Rev Cancer. 2009; 9: 167-81. https://doi.org/http://www.nature.com/nrc/ journal/v9/n3/suppinfo/nrc2583_S1.html.

4. Wang V, Li C, Lin M, Welch W, Bell D, Wong YF, Berkowitz R, Mok SC, Bandera CA. Ovarian cancer is a heterogeneous disease. Cancer Genetics and Cytogenetics. 2005; 161: 170-3. https://doi.org/http://dx.doi.org/10.1016/j. cancergencyto.2004.12.014

5. Wei W, Dizon D, Vathipadiekal V, Birrer MJ. Ovarian cancer: genomic analysis. Ann Oncol. 2013; 24: x7-15. https://doi.org/10.1093/annonc/mdt462.

6. Nakamura K, Sawada K, Kinose Y, Yoshimura A, Toda A, Nakatsuka E, Hashimoto K, Mabuchi S, Morishige KI, Kurachi H, Lengyel E, Kimura T. Exosomes Promote Ovarian Cancer Cell Invasion through Transfer of CD44 to Peritoneal Mesothelial Cells. Mol Cancer Res. 2016; 15: 78-92. https://doi.org/10.1158/1541-7786. mcr-16-0191.
7. Escrevente C, Keller S, Altevogt P, Costa J. Interaction and uptake of exosomes by ovarian cancer cells. BMC Cancer. 2011; 11: 108. https://doi.org/10.1186/1471-2407-11-108.

8. Bang C, Thum T. Exosomes: New players in cell-cell communication. The International Journal of Biochemistry \& Cell Biology. 2012; 44: 2060-4. https://doi.org/http:// dx.doi.org/10.1016/j.biocel.2012.08.007.

9. Thery C, Zitvogel L, Amigorena S. Exosomes: composition, biogenesis and function. Nat Rev Immunol. 2002; 2: 56979. https://doi.org/10.1038/nri855.

10. Théry C, Amigorena S, Raposo G, Clayton A. (2001). Isolation and Characterization of Exosomes from Cell Culture Supernatants and Biological Fluids. Current Protocols in Cell Biology: John Wiley \& Sons, Inc.

11. Brinton LT, Sloane HS, Kester M, Kelly KA. Formation and role of exosomes in cancer. Cell Mol Life Sci. 2015; 72: 659-71. https://doi.org/10.1007/s00018-014-1764-3.

12. Peinado H, Alečković M, Lavotshkin S, Matei I, CostaSilva B, Moreno-Bueno G, Hergueta-Redondo M, Williams C, García-Santos G, Nitadori-Hoshino A, Hoffman C, Badal K, Garcia BA, et al. Melanoma exosomes educate bone marrow progenitor cells toward a pro-metastatic phenotype through MET. Nature medicine. 2012; 18: 883-91. https:// doi.org/10.1038/nm.2753.

13. Taylor DD, Gercel-Taylor C. MicroRNA signatures of tumor-derived exosomes as diagnostic biomarkers of ovarian cancer. Gynecologic Oncology. 2008; 110: 13-21. https://doi.org/http://dx.doi.org/10.1016/j. ygyno.2008.04.033.

14. Doufekas K, Olaitan A. Clinical epidemiology of epithelial ovarian cancer in the UK. International Journal of Women's Health. 2014; 6: 537-45. https://doi.org/10.2147/IJWH. S40894.

15. Rosen DG, Yang G, Liu G, Mercado-Uribe I, Chang B, Xiao X, Zheng J, Xue FX, Liu J. Ovarian cancer: pathology, biology, and disease models. Frontiers in bioscience. 2009; 14: 2089-102.

16. Permuth-Wey J, Sellers TA. (2009). Epidemiology of Ovarian Cancer. Cancer Epidemiology. (Totowa: Humana Press), pp. 413-37.

17. Matulonis UA, Sood AK, Fallowfield L, Howitt BE, Sehouli J, Karlan BY. Ovarian cancer. Nature Reviews Disease Primers. 2016; 2: 16061. https://doi.org/10.1038/ $\operatorname{nrdp} .2016 .61$.

18. Chen VW, Ruiz B, Killeen JL, Coté TR, Wu XC, Correa CN, Howe HL. Pathology and classification of ovarian tumors. Cancer. 2003; 97: 2631-42. https://doi.org/10.1002/cncr.11345.

19. Prat J, FIGO Committee on Gynecologic Oncology. FIGO's staging classification for cancer of the ovary, fallopian tube, and peritoneum: abridged republication. Journal of Gynecologic Oncology. 2015; 26: 87-9. https://doi.org/10.3802/jgo.2015.26.2.87.

20. Rossing MA, Wicklund KG, Cushing-Haugen KL, Weiss NS. Predictive value of symptoms for early detection of 
ovarian cancer. J Natl Cancer Inst. 2010; 102: 222-9. https:// doi.org/10.1093/jnci/djp500.

21. Antoniou A, Pharoah PDP, Narod S, Risch HA, Eyfjord JE, Hopper JL, Loman N, Olsson H, Johannsson O, Borg Å, Pasini B, Radice P, Manoukian S, et al. Average Risks of Breast and Ovarian Cancer Associated with BRCA1 or BRCA2 Mutations Detected in Case Series Unselected for Family History: A Combined Analysis of 22 Studies. The American Journal of Human Genetics. 2003; 72: 1117-30. https://doi.org/http://dx.doi.org/10.1086/375033.

22. Ford D, Easton DF, Peto J. Estimates of the gene frequency of BRCA1 and its contribution to breast and ovarian cancer incidence. American Journal of Human Genetics. 1995; 57: 1457-62.

23. Australia AGC. (2017). Familial Risk Assesment FRA-BOC.

24. Antoniou AC, Pharoah PP, Smith P, Easton DF. The BOADICEA model of genetic susceptibility to breast and ovarian cancer. Br J Cancer. 2004; 91: 1580-90.

25. Permuth JB, Reid B, Earp M, Chen YA, Monteiro AN, Chen Z, Aocs Study G, Chenevix-Trench G, Fasching PA, Beckmann MW, Lambrechts D, Vanderstichele A, Van Niewenhuyse E, et al. Inherited variants affecting RNA editing may contribute to ovarian cancer susceptibility: results from a large-scale collaboration. Oncotarget. 2016; 7: 72381-94. https://doi.org/10.18632/oncotarget.10546.

26. Cuellar-Partida G, Lu Y, Dixon SC, Fasching PA, Hein A, Burghaus S, Beckmann MW, Lambrechts D, Van Nieuwenhuysen E, Vergote I, Vanderstichele A, Doherty JA, Rossing MA, et al. Assessing the genetic architecture of epithelial ovarian cancer histological subtypes. Hum Genet. 2016; 135: 741-56. https://doi.org/10.1007/ s00439-016-1663-9.

27. Alsop K, Fereday S, Meldrum C, deFazio A, Emmanuel C, George J, Dobrovic A, Birrer MJ, Webb PM, Stewart C, Friedlander M, Fox S, Bowtell D, et al. BRCA Mutation Frequency and Patterns of Treatment Response in BRCA Mutation-Positive Women With Ovarian Cancer: A Report From the Australian Ovarian Cancer Study Group. Journal of Clinical Oncology. 2012; 30: 2654-63. https://doi. org/10.1200/JCO.2011.39.8545.

28. Collaborative Group on Epidemiological Studies of Ovarian Cancer. Ovarian Cancer and Body Size: Individual Participant Meta-Analysis Including 25,157 Women with Ovarian Cancer from 47 Epidemiological Studies. PLoS Medicine. 2012; 9: e1001200. https://doi.org/10.1371/ journal.pmed.1001200.

29. Gong TT, Wu QJ, Vogtmann E, Lin B, Wang YL. Age at menarche and risk of ovarian cancer: a meta-analysis of epidemiological studies. International journal of cancer. 2013; 132: 2894-900. https://doi.org/10.1002/ijc.27952.

30. Kim A, Ueda Y, Naka T, Enomoto T. Therapeutic strategies in epithelial ovarian cancer. J Exp Clin Cancer Res. 2012; 31: 14. https://doi.org/10.1186/1756-9966-31-14.
31. Tan DS, Agarwal R, Kaye SB. Mechanisms of transcoelomic metastasis in ovarian cancer. Lancet Oncol. 2006; 7: 92534. https://doi.org/10.1016/s1470-2045(06)70939-1.

32. Pradeep S, Kim SW, Wu SY, Nishimura M, ChaluvallyRaghavan P, Miyake T, Pecot CV, Kim SJ, Choi HJ, Bischoff FZ, Mayer JA, Huang L, Nick AM, et al. Hematogenous metastasis of ovarian cancer: Rethinking mode of spread. Cancer cell. 2014; 26: 77-91. https://doi. org/10.1016/j.ccr.2014.05.002.

33. Naora H, Montell DJ. Ovarian cancer metastasis: integrating insights from disparate model organisms. Nat Rev Cancer. 2005; 5: 355-66. https://doi.org/10.1038/nrc1611.

34. Bilyk O, Coatham M, Jewer M, Postovit LM. Epithelial-toMesenchymal Transition in the Female Reproductive Tract: From Normal Functioning to Disease Pathology. Frontiers in Oncology. 2017; 7: 145. https://doi.org/10.3389/ fonc.2017.00145.

35. Lengyel E. Ovarian Cancer Development and Metastasis. The American Journal of Pathology. 2010; 177: 1053-64. https://doi.org/10.2353/ajpath.2010.100105.

36. Neesham D. Ovarian cancer screening. Aust Fam Physician. 2007; 36: 126-8.

37. Moss EL, Hollingworth J, Reynolds TM. The role of CA125 in clinical practice. Journal of Clinical Pathology. 2005; 58: 308-12. https://doi.org/10.1136/jcp.2004.018077.

38. Scholler N, Urban N. CA125 in Ovarian Cancer. Biomarkers in medicine. 2007; 1: 513-23. https://doi. org/10.2217/17520363.1.4.513.

39. Felder M, Kapur A, Gonzalez-Bosquet J, Horibata S, Heintz J, Albrecht R, Fass L, Kaur J, Hu K, Shojaei H, Whelan RJ, Patankar MS. MUC16 (CA125): tumor biomarker to cancer therapy, a work in progress. Molecular Cancer. 2014; 13: 129. https://doi.org/10.1186/1476-4598-13-129.

40. Buys SS, Partridge E, Black A, Johnson CC, Lamerato L, Isaacs C, Reding DJ, Greenlee RT, Yokochi LA, Kessel B, Crawford ED, Church TR, Andriole GL, et al. Effect of screening on ovarian cancer mortality: the Prostate, Lung, Colorectal and Ovarian (PLCO) Cancer Screening Randomized Controlled Trial. Jama. 2011; 305: 2295-303. https://doi.org/10.1001/jama.2011.766.

41. Zhao Z, Yang Y, Zeng Y, He M. A microfluidic ExoSearch chip for multiplexed exosome detection towards bloodbased ovarian cancer diagnosis. Lab Chip. 2016; 16: 48996. https://doi.org/10.1039/c5lc01117e.

42. Jayson GC, Kohn EC, Kitchener HC, Ledermann JA. Ovarian cancer. The Lancet. 384: 1376-88. https://doi.org/ http://dx.doi.org/10.1016/S0140-6736(13)62146-7.

43. Duffy MJ. Tumor markers in clinical practice: a review focusing on common solid cancers. Med Princ Pract. 2013; 22: 4-11. https://doi.org/10.1159/000338393.

44. Kobayashi E, Ueda Y, Matsuzaki S, Yokoyama T, Kimura T, Yoshino K, Fujita M, Kimura T, Enomoto T. Biomarkers for screening, diagnosis, and monitoring of ovarian cancer. 
Cancer Epidemiol Biomarkers Prev. 2012; 21: 1902-12. https://doi.org/10.1158/1055-9965.epi-12-0646.

45. Kamat AA, Baldwin M, Urbauer D, Dang D, Han LY, Godwin A, Karlan BY, Simpson JL, Gershenson DM, Coleman RL, Bischoff FZ, Sood AK. Plasma Cell-free DNA in Ovarian Cancer: An Independent Prognostic Biomarker. Cancer. 2010; 116: 1918-25. https://doi.org/10.1002/ cncr.24997.

46. Shao X, He Y, Ji M, Chen X, Qi J, Shi W, Hao T, Ju S. Quantitative analysis of cell-free DNA in ovarian cancer. Oncology Letters. 2015; 10: 3478-82. https://doi. org/10.3892/ol.2015.3771.

47. Zheng H, Zhang L, Zhao Y, Yang D, Song F, Wen Y, Hao Q, $\mathrm{Hu}$ Z, Zhang W, Chen K. Plasma miRNAs as diagnostic and prognostic biomarkers for ovarian cancer. PLoS One. 2013; 8: e77853. https://doi.org/10.1371/journal.pone.0077853.

48. Shalaby T, Fiaschetti G, Baumgartner M, Grotzer MA. MicroRNA Signatures as Biomarkers and Therapeutic Target for CNS Embryonal Tumors: The Pros and the Cons. International Journal of Molecular Sciences. 2014; 15: 21554-86. https://doi.org/10.3390/ijms151121554.

49. Witwer KW. Circulating MicroRNA Biomarker Studies: Pitfalls and Potential Solutions. Clinical Chemistry. 2015; 61: 56-63. https://doi.org/10.1373/clinchem.2014.221341.

50. Tiberio P, Callari M, Angeloni V, Daidone MG, Appierto V. Challenges in Using Circulating miRNAs as Cancer Biomarkers. BioMed Research International. 2015; 2015: 10. https://doi.org/10.1155/2015/731479.

51. Vallabhajosyula P, Korutla L, Habertheuer A, Yu M, Rostami S, Yuan CX, Reddy S, Liu C, Korutla V, Koeberlein B, Trofe-Clark J, Rickels MR, Naji A. Tissuespecific exosome biomarkers for noninvasively monitoring immunologic rejection of transplanted tissue. The Journal of Clinical Investigation. 2017; 127: 1375-91. https://doi. org/10.1172/JCI87993.

52. Kuk C, Kulasingam V, Gunawardana CG, Smith CR, Batruch I, Diamandis EP. Mining the Ovarian Cancer Ascites Proteome for Potential Ovarian Cancer Biomarkers. Molecular \& Cellular Proteomics. 2009; 8: 661-9. https:// doi.org/10.1074/mcp.M800313-MCP200.

53. Kobayashi M, Salomon C, Tapia J, Illanes SE, Mitchell $\mathrm{MD}$, Rice GE. Ovarian cancer cell invasiveness is associated with discordant exosomal sequestration of Let-7 miRNA and miR-200. J Transl Med. 2014; 12: 4. https://doi. org/10.1186/1479-5876-12-4.

54. Li X, Wang X. The emerging roles and therapeutic potential of exosomes in epithelial ovarian cancer. Molecular Cancer. 2017; 16: 92. https://doi.org/10.1186/s12943-017-0659-y.

55. Munson P, Shukla A. Exosomes: Potential in Cancer Diagnosis and Therapy. Medicines (Basel). 2015; 2: 31027. https://doi.org/10.3390/medicines2040310.

56. Filipazzi P, Burdek M, Villa A, Rivoltini L, Huber V. Recent advances on the role of tumor exosomes in immunosuppression and disease progression. Semin Cancer Biol. 2012; 22: 342-9. https://doi.org/10.1016/j.semcancer.2012.02.005.

57. Colombo M, Raposo G, Thery C. Biogenesis, secretion, and intercellular interactions of exosomes and other extracellular vesicles. Annu Rev Cell Dev Biol. 2014; 30: 255-89. https:// doi.org/10.1146/annurev-cellbio-101512-122326.

58. Salomon C, Ryan J, Sobrevia L, Kobayashi M, Ashman K, Mitchell M, Rice GE. Exosomal signaling during hypoxia mediates microvascular endothelial cell migration and vasculogenesis. PLoS One. 2013; 8: e68451. https://doi. org/10.1371/journal.pone.0068451.

59. Rice GE, Scholz-Romero K, Sweeney E, Peiris H, Kobayashi M, Duncombe G, Mitchell MD, Salomon C. The Effect of Glucose on the Release and Bioactivity of Exosomes From First Trimester Trophoblast Cells. J Clin Endocrinol Metab. 2015; 100: E1280-8. https://doi. org/10.1210/jc.2015-2270.

60. Johnstone RM, Adam M, Hammond JR, Orr L, Turbide C. Vesicle formation during reticulocyte maturation. Association of plasma membrane activities with released vesicles (exosomes). J Biol Chem. 1987; 262: 9412-20.

61. Keller S, Sanderson MP, Stoeck A, Altevogt P. Exosomes: From biogenesis and secretion to biological function. Immunology Letters. 2006; 107: 102-8. https://doi.org/ http://dx.doi.org/10.1016/j.imlet.2006.09.005.

62. Kowal J, Tkach M, Théry C. Biogenesis and secretion of exosomes. Current Opinion in Cell Biology. 2014; 29: 116-25. https://doi.org/http://dx.doi.org/10.1016/j. ceb.2014.05.004.

63. Ostrowski M, Carmo NB, Krumeich S, Fanget I, Raposo G, Savina A, Moita CF, Schauer K, Hume AN, Freitas RP, Goud B, Benaroch P, Hacohen N, et al. Rab27a and Rab27b control different steps of the exosome secretion pathway. Nat Cell Biol. 2010; 12: 19-30. https://doi.org/http://www. nature.com/ncb/journal/v12/n1/suppinfo/ncb2000_S1.html.

64. Johnsen KB, Gudbergsson JM, Skov MN, Pilgaard L, Moos T, Duroux M. A comprehensive overview of exosomes as drug delivery vehicles - Endogenous nanocarriers for targeted cancer therapy. Biochimica et Biophysica Acta. 2014; 1846: 75-87. https://doi.org/http://dx.doi. org/10.1016/j.bbcan.2014.04.005.

65. Raposo G, Nijman HW, Stoorvogel W, Liejendekker R, Harding CV, Melief CJ, Geuze HJ. B lymphocytes secrete antigen-presenting vesicles. J Exp Med. 1996; 183: 1161-72.

66. Denzer K, van Eijk M, Kleijmeer MJ, Jakobson E, de Groot C, Geuze HJ. Follicular dendritic cells carry MHC class II-expressing microvesicles at their surface. J Immunol. 2000; 165: 1259-65.

67. Clayton A, Turkes A, Dewitt S, Steadman R, Mason MD, Hallett MB. Adhesion and signaling by B cell-derived exosomes: the role of integrins. Faseb j. 2004; 18: 977-9. https://doi.org/10.1096/fj.03-1094fje. 
68. Morelli AE, Larregina AT, Shufesky WJ, Sullivan ML, Stolz DB, Papworth GD, Zahorchak AF, Logar AJ, Wang Z, Watkins SC, Falo LD Jr, Thomson AW. Endocytosis, intracellular sorting, and processing of exosomes by dendritic cells. Blood. 2004; 104: 3257-66. https://doi. org/10.1182/blood-2004-03-0824.

69. Svensson KJ, Christianson HC, Wittrup A, BourseauGuilmain E, Lindqvist E, Svensson LM, Morgelin M, Belting M. Exosome uptake depends on ERK1/2-heat shock protein 27 signaling and lipid Raft-mediated endocytosis negatively regulated by caveolin-1. J Biol Chem. 2013; 288: 17713-24. https://doi.org/10.1074/jbc.M112.445403.

70. Whiteside TL. The potential of tumor-derived exosomes for noninvasive cancer monitoring. Expert review of molecular diagnostics. 2015; 15: 1293-310. https://doi.org/10.1586/14 737159.2015 .1071666$.

71. Nawaz M, Fatima F, Nazarenko I, Ekstrom K, Murtaza I, Anees M, Sultan A, Neder L, Camussi G, Valadi H, Squire JA, Kislinger T. Extracellular vesicles in ovarian cancer: applications to tumor biology, immunotherapy and biomarker discovery. Expert Rev Proteomics. 2016; 13: 395-409. https://doi.org/10.1586/14789450.2016.1165613.

72. Melo SA, Sugimoto H, O'Connell JT, Kato N, Villanueva A, Vidal A, Qiu L, Vitkin E, Perelman LT, Melo CA, Lucci A, Ivan C, Calin GA, et al. Cancer exosomes perform cell-independent microRNA biogenesis and promote tumorigenesis. Cancer Cell. 2014; 26: 707-21. https://doi. org/10.1016/j.ccell.2014.09.005.

73. Paranjape T, Slack FJ, Weidhaas JB. MicroRNAs: tools for cancer diagnostics. Gut. 2009; 58: 1546-54. https://doi. org/10.1136/gut.2009.179531.

74. Vong S, Kalluri R. The Role of Stromal Myofibroblast and Extracellular Matrix in Tumor Angiogenesis. Genes Cancer. 2011; 2: 1139-45. https://doi.org/10.1177/1947601911423940.

75. Philip R, Heiler S, Mu W, Buchler MW, Zoller M, Thuma F. Claudin-7 promotes the epithelial-mesenchymal transition in human colorectal cancer. Oncotarget. 2015; 6: 2046-63. https://doi.org/10.18632/oncotarget.2858.

76. Raposo G, Stoorvogel W. Extracellular vesicles: Exosomes, microvesicles, and friends. The Journal of Cell Biology. 2013; 200: 373.

77. Van Deun J, Mestdagh P, Sormunen R, Cocquyt V, Vermaelen K, Vandesompele J, Bracke M, De Wever O, Hendrix A. The impact of disparate isolation methods for extracellular vesicles on downstream RNA profiling. J Extracell Vesicles. 2014; 3. https://doi.org/10.3402/jev.v3.24858.

78. Cvjetkovic A, Lötvall J, Lässer C. The influence of rotor type and centrifugation time on the yield and purity of extracellular vesicles. Journal of Extracellular Vesicles. 2014; 3. 10.3402/ jev.v3.23111. https://doi.org/10.3402/jev.v3.23111.

79. Gardiner C, Di Vizio D, Sahoo S, Thery C, Witwer KW, Wauben M, Hill AF. Techniques used for the isolation and characterization of extracellular vesicles: results of a worldwide survey. J Extracell Vesicles. 2016; 5: 32945. https://doi.org/10.3402/jev.v5.32945.

80. Livshits MA, Khomyakova E, Evtushenko EG, Lazarev VN, Kulemin NA, Semina SE, Generozov EV, Govorun VM. Corrigendum: Isolation of exosomes by differential centrifugation: Theoretical analysis of a commonly used protocol. Scientific Reports. 2016; 6: 21447. https://doi. org/10.1038/srep21447.

81. Lobb RJ, Becker M, Wen SW, Wong CS, Wiegmans AP, Leimgruber A, Moller A. Optimized exosome isolation protocol for cell culture supernatant and human plasma. J Extracell Vesicles. 2015; 4: 27031. https://doi.org/10.3402/ jev.v4.27031.

82. Lotvall J, Hill AF, Hochberg F, Buzas EI, Di Vizio D, Gardiner C, Gho YS, Kurochkin IV, Mathivanan S, Quesenberry P, Sahoo S, Tahara H, Wauben $\mathrm{MH}$, et al. Minimal experimental requirements for definition of extracellular vesicles and their functions: a position statement from the International Society for Extracellular Vesicles. J Extracell Vesicles. 2014; 3: 26913. https://doi. org/10.3402/jev.v3.26913.

83. Witwer KW, Buzas EI, Bemis LT, Bora A, Lasser C, Lotvall J, Nolte-'t Hoen EN, Piper MG, Sivaraman S, Skog J, Thery C, Wauben MH, Hochberg F. Standardization of sample collection, isolation and analysis methods in extracellular vesicle research. J Extracell Vesicles. 2013; 2. https://doi. org/10.3402/jev.v2i0.20360.

84. An T, Qin S, Xu Y, Tang Y, Huang Y, Situ B, Inal JM, Zheng L. Exosomes serve as tumour markers for personalized diagnostics owing to their important role in cancer metastasis. J Extracell Vesicles. 2015; 4: 27522. https://doi. org/10.3402/jev.v4.27522.

85. Garnier D, Magnus N, Meehan B, Kislinger T, Rak J. Qualitative changes in the proteome of extracellular vesicles accompanying cancer cell transition to mesenchymal state. Exp Cell Res. 2013; 319: 2747-57. https://doi.org/10.1016/j. yexcr.2013.08.003.

86. Li J, Sherman-Baust CA, Tsai-Turton M, Bristow RE, Roden RB, Morin PJ. Claudin-containing exosomes in the peripheral circulation of women with ovarian cancer. BMC Cancer. 2009; 9: 244. https://doi. org/10.1186/1471-2407-9-244.

87. Liang B, Peng P, Chen S, Li L, Zhang M, Cao D, Yang J, Li H, Gui T, Li X, Shen K. Characterization and proteomic analysis of ovarian cancer-derived exosomes. Journal of Proteomics. 2013; 80: 171-82. https://doi.org/http://dx.doi. org/10.1016/j.jprot.2012.12.029.

88. Vaksman O, Tropé C, Davidson B, Reich R. Exosome-derived miRNAs and ovarian carcinoma progression. Carcinogenesis. 2014; 35: 2113-20. https://doi.org/10.1093/carcin/bgu130.

89. Resnick KE, Alder H, Hagan JP, Richardson DL, Croce CM, Cohn DE. The detection of differentially expressed microRNAs from the serum of ovarian cancer patients using 
a novel real-time PCR platform. Gynecol Oncol. 2009; 112: 55-9. https://doi.org/10.1016/j.ygyno.2008.08.036.

90. Graves LE, Ariztia EV, Navari JR, Matzel HJ, Stack MS, Fishman DA. Proinvasive properties of ovarian cancer ascites-derived membrane vesicles. Cancer Res. 2004; 64: 7045-9. https://doi.org/10.1158/0008-5472.can-04-1800.

91. Runz S, Keller S, Rupp C, Stoeck A, Issa Y, Koensgen D, Mustea A, Sehouli J, Kristiansen G, Altevogt P. Malignant ascites-derived exosomes of ovarian carcinoma patients contain CD24 and EpCAM. Gynecologic Oncology. 2007; 107: 563-71. https://doi.org/http://dx.doi.org/10.1016/j. ygyno.2007.08.064.

92. Au Yeung CL, Co NN, Tsuruga T, Yeung TL, Kwan SY, Leung CS, Li Y, Lu ES, Kwan K, Wong KK, Schmandt R, Lu KH, Mok SC. Exosomal transfer of stroma-derived miR21 confers paclitaxel resistance in ovarian cancer cells through targeting APAF1. Nat Commun. 2016; 7: 11150. https://doi.org/10.1038/ncomms 11150 .

93. Azmi AS, Bao B, Sarkar FH. Exosomes in Cancer Development, Metastasis and Drug Resistance: A Comprehensive Review. Cancer metastasis reviews. 2013; 32: 623-42. 10.1007/s10555-013-9441-9. https://doi.org/10.1007/s10555-013-9441-9.

94. Safaei R, Larson BJ, Cheng TC, Gibson MA, Otani S, Naerdemann W, Howell SB. Abnormal lysosomal trafficking and enhanced exosomal export of cisplatin in drug-resistant human ovarian carcinoma cells. Mol Cancer Ther. 2005; 4: 1595-604. https://doi.org/10.1158/15357163.mct-05-0102.

95. Yin J, Yan X, Yao X, Zhang Y, Shan Y, Mao N, Yang Y, Pan L. Secretion of annexin A3 from ovarian cancer cells and its association with platinum resistance in ovarian cancer patients. Journal of Cellular and Molecular Medicine. 2012; 16: 337-48. https://doi. org/10.1111/j.1582-4934.2011.01316.x.

96. Yeo RWY, Lai RC, Zhang B, Tan SS, Yin Y, Teh BJ, Lim SK. Mesenchymal stem cell: An efficient mass producer of exosomes for drug delivery. Advanced Drug Delivery Reviews. 2013; 65: 336-41. https://doi.org/http://dx.doi. org/10.1016/j.addr.2012.07.001.

97. Ha D, Yang N, Nadithe V. Exosomes as therapeutic drug carriers and delivery vehicles across biological membranes: current perspectives and future challenges. Acta Pharmaceutica Sinica B. 2016; 6: 287-96. https://doi. org/http://dx.doi.org/10.1016/j.apsb.2016.02.001.

98. Yang T, Martin P, Fogarty B, Brown A, Schurman K, Phipps R, Yin VP, Lockman P, Bai S. Exosome Delivered Anticancer Drugs Across the Blood-Brain Barrier for Brain Cancer Therapy in Danio Rerio. Pharmaceutical research. 2015; 32: 2003-14. https://doi.org/10.1007/ s11095-014-1593-y.

99. Tian Y, Li S, Song J, Ji T, Zhu M, Anderson GJ, Wei J, Nie G. A doxorubicin delivery platform using engineered natural membrane vesicle exosomes for targeted tumor therapy. Biomaterials. 2014; 35: 2383-90. https://doi.org/ http://dx.doi.org/10.1016/j.biomaterials.2013.11.083.

100. Szajnik M, Derbis M, Lach M, Patalas P, Michalak M, Drzewiecka H, Szpurek D, Nowakowski A, Spaczynski M, Baranowski W, Whiteside TL. Exosomes in Plasma of Patients with Ovarian Carcinoma: Potential Biomarkers of Tumor Progression and Response to Therapy. Gynecology \& obstetrics (Sunnyvale, Calif). 2013. https://doi. org/10.4172/2161-0932.S4-003.

101. Chang S, Kohrt H, Maecker HT. Monitoring the Immune Competence of Cancer Patients to Predict Outcome. Cancer immunology, immunotherapy. 2014; 63: 713-9. https://doi. org/10.1007/s00262-014-1521-3.

102. Galon J, Pages F, Marincola FM, Thurin M, Trinchieri G, Fox BA, Gajewski TF, Ascierto PA. The immune score as a new possible approach for the classification of cancer. J Transl Med. 2012; 10: 1. https://doi. org/10.1186/1479-5876-10-1.

103. Dolo V, D’Ascenzo S, Violini S, Pompucci L, Festuccia C, Ginestra A, Vittorelli ML, Canevari S, Pavan A. Matrixdegrading proteinases are shed in membrane vesicles by ovarian cancer cells in vivo and in vitro. Clinical \& Experimental Metastasis. 1999; 17: 131-40. https://doi. org/10.1023/a:1006500406240.

104. Li QL, Bu N, Yu YC, Hua W, Xin XY. Exvivo Experiments of Human Ovarian Cancer Ascites-Derived Exosomes Presented by Dendritic Cells Derived from Umbilical Cord Blood for Immunotherapy Treatment. Clinical Medicine Oncology. 2008; 2: 461-7. https://doi.org/10.4137/CMO. S776.

105. Taylor DD, Gercel-Taylor C. MicroRNA signatures of tumor-derived exosomes as diagnostic biomarkers of ovarian cancer. Gynecol Oncol. 2008; 110: 13-21. https:// doi.org/10.1016/j.ygyno.2008.04.033.

106. Peng P, Yan Y, Keng S. Exosomes in the ascites of ovarian cancer patients: origin and effects on anti-tumor immunity. Oncol Rep. 2011; 25: 749-62. https://doi.org/10.3892/ or.2010.1119.

107. Ying X, Wu Q, Wu X, Zhu Q, Wang X, Jiang L, Chen $\mathrm{X}$, Wang $\mathrm{X}$. Epithelial ovarian cancer-secreted exosomal miR-222-3p induces polarization of tumor-associated macrophages. Oncotarget. 2016; 7: 43076-87. https://doi. org/10.18632/oncotarget.9246.

108. Im H, Shao H, Park YI, Peterson VM, Castro CM, Weissleder R, Lee H. Label-free detection and molecular profiling of exosomes with a nano-plasmonic sensor. Nat Biotech. 2014; 32: 490-5.

109. Zhang P, He M, Zeng Y. Ultrasensitive microfluidic analysis of circulating exosomes using a nanostructured graphene oxide/polydopamine coating. Lab Chip. 2016; 16: 3033-42. https://doi.org/10.1039/c6lc00279j.

110. Cho JA, Park H, Lim EH, Kim KH, Choi JS, Lee JH, Shin JW, Lee KW. Exosomes from ovarian cancer cells induce adipose tissue-derived mesenchymal stem cells to 
acquire the physical and functional characteristics of tumorsupporting myofibroblasts. Gynecologic Oncology. 2011; 123: 379-86. https://doi.org/10.1016/j.ygyno.2011.08.005.

111. Sinha A, Ignatchenko V, Ignatchenko A, Mejia-Guerrero S, Kislinger T. In-depth proteomic analyses of ovarian cancer cell line exosomes reveals differential enrichment of functional categories compared to the NCI 60 proteome. Biochemical and Biophysical Research Communications. 2014; 445: 694-701. https://doi.org/10.1016/j.bbrc.2013.12.070.

112. Enriquez VA, Cleys ER, Da Silveira JC, Spillman MA, Winger QA, Bouma GJ. High LIN28A Expressing Ovarian Cancer Cells Secrete Exosomes That Induce Invasion and Migration in HEK293 Cells. BioMed Research International. 2015; 2015: 13. https://doi. org/10.1155/2015/701390.

113. Yi H, Ye J, Yang XM, Zhang LW, Zhang ZG, Chen YP. High-grade ovarian cancer secreting effective exosomes in tumor angiogenesis. International Journal of Clinical and Experimental Pathology. 2015; 8: 5062-70.

114. Yi H, Zheng X, Song J, Shen R, Su Y, Lin D. Exosomes mediated pentose phosphate pathway in ovarian cancer metastasis: a proteomics analysis. International Journal of Clinical and Experimental Pathology. 2015; 8: 15719-28.

115. Reza AM, Choi YJ, Yasuda H, Kim JH. Human adipose mesenchymal stem cell-derived exosomal-miRNAs are critical factors for inducing anti-proliferation signalling to A2780 and SKOV-3 ovarian cancer cells. Scientific Reports. 2016; 6: 38498. https://doi.org/10.1038/srep38498.

116. Kanlikilicer P, Rashed MH, Bayraktar R, Mitra R, Ivan C, Aslan B, Zhang X, Filant J, Silva AM, RodriguezAguayo C, Bayraktar E, Pichler M, Ozpolat B, et al. Ubiquitous Release of Exosomal Tumor Suppressor miR-6126 from Ovarian Cancer Cells. Cancer Research. 2016; 76: 7194-207. https://doi.org/10.1158/0008-5472. can-16-0714.

117. Crow J, Atay S, Banskota S, Artale B, Schmitt S, Godwin AK. Exosomes as mediators of platinum resistance in ovarian cancer. Oncotarget. 2017; 8: 11917-36. https://doi. org/10.18632/oncotarget.14440.

118. Yokoi A, Yoshioka Y, Yamamoto Y, Ishikawa M, Ikeda SI, Kato T, Kiyono T, Takeshita F, Kajiyama H, Kikkawa
F, Ochiya T. Malignant extracellular vesicles carrying MMP1 mRNA facilitate peritoneal dissemination in ovarian cancer. Nature Communications. 2017; 8: 14470. 10.1038/ncomms14470 https:/www.nature.com/articles/ ncomms14470\#supplementary-information.

119. Rank A, Liebhardt S, Zwirner J, Burges A, Nieuwland R, Toth B. Circulating Microparticles in Patients with Benign and Malignant Ovarian Tumors. Anticancer Research. 2012; 32: 2009-14.

120. Shender VO, Pavlyukov MS, Ziganshin RH, Arapidi GP, Kovalchuk SI, Anikanov NA, Altukhov IA, Alexeev DG, Butenko IO, Shavarda AL, Khomyakova EB, Evtushenko E, Ashrafyan LA, et al. Proteome-Metabolome Profiling of Ovarian Cancer Ascites Reveals Novel Components Involved in Intercellular Communication. Molecular \& Cellular Proteomics. 2014; 13: 3558-71. https://doi. org/10.1074/mcp.M114.041194.

121. Claussen C, Rausch AV, Lezius S, Amirkhosravi A, Davila M, Francis JL, Hisada YM, Mackman N, Bokemeyer C, Schmalfeldt B, Mahner S, Langer F. Microvesicleassociated tissue factor procoagulant activity for the preoperative diagnosis of ovarian cancer. Thrombosis Research. 2016; 141: 39-48. http://dx.doi.org/10.1016/j. thromres.2016.03.002.

122. Lea J, Sharma R, Yang F, Zhu H, Ward ES, Schroit AJ. Detection of phosphatidylserine-positive exosomes as a diagnostic marker for ovarian malignancies: a proof of concept study. Oncotarget. 2017; 8: 14395-407. https://doi. org/10.18632/oncotarget.14795.

123. Escrevente C, Grammel N, Kandzia S, Zeiser J, Tranfield EM, Conradt HS, Costa J. Sialoglycoproteins and N-Glycans from Secreted Exosomes of Ovarian Carcinoma Cells. PLoS ONE. 2013; 8: e78631. https://doi.org/10.1371/ journal.pone.0078631.

124. Gomes J, Gomes-Alves P, Carvalho SB, Peixoto C, Alves PM, Altevogt P, Costa J. Extracellular Vesicles from Ovarian Carcinoma Cells Display Specific Glycosignatures. Biomolecules. 2015; 5: 1741-61. https://doi.org/10.3390/ biom5031741. 